Teologia i Moralność, volumen 13(2018), numer 2(24)

doi: 10.14746/tim.2018.24.2.1

ORCID: 0000-0002-1857-1018

\author{
MARIAN MACHINEK \\ Uniwersytet Warmińsko-Mazurski \\ Wydział Teologii
}

\title{
Przesłanie Humanae vitae z perspektywy pięćdziesiątej rocznicy ogłoszenia encykliki
}

Nie ulega wątpliwości, że Humanae vitae była najbardziej kontrowersyjnym dokumentem Magisterium Kościoła w XX wieku. Zapowiedziana przez Pawła VI już w 1964 roku i oczekiwana przez kilka lat, przywitana została przez jednych z wielką wdzięcznością i podziwem dla odwagi papieża ${ }^{1}$, przez innych natomiast z rozczarowaniem albo wręcz oburzeniem. Encyklika Pawła VI stała się znakiem pęknięcia nie tylko w obszarze nauki moralnej Kościoła katolickiego, ale w odniesieniu do katolickiej tożsamości jako takiej, szczególnie w kwestii relacji sumienia wierzących do Urzędu Nauczycielskiego Kościoła. Jak to zwykle bywa w przypadku tego typu kontrowersji, dyskusja skoncentrowała się na jednym aspekcie papieskiego dokumentu, jakim była negatywna ocena moralna stosowania antykoncepcji, przez co wiele innych cennych aspektów encykliki nie zostało w ogóle dostrzeżonych.

Pięćdziesiąta rocznica ogłoszenia dokumentu jest niewątpliwie okazją do analizy recepcji zawartych $\mathrm{w}$ nim wskazań moralnych oraz dyskusji z nimi związanych w czasie ostatnich pięciu dekad. Ramy tego niewielkiego artykułu zmuszają oczywiście do zacieśnienia omawianej problematyki. Jej przedmiotem będzie pogłębiona analiza argumentacji encykliki w świetle nauczania następców Pawła VI, ale także w świetle zarzutów wobec zaprezentowanego w niej sposobu rozumowania. Wśród nich najpoważniejszym wydaje się zarzut tzw. biologizmu bądź też naturalizmu, którym rzekomo naznaczona jest argumentacja encykliki. Istotne będzie także spojrzenie na aktualny stan dyskusji w świetle nauczania papieża Franciszka.

\footnotetext{
${ }^{1}$ Karl-Alfred Odin podaje, że prawosławny Patriarcha Athenagoras miał w imieniu całego prawosławia zadeklarować całkowitą zgodność z przesłaniem Humanae vitae (por. Odin 1968, s. 49).
} 


\section{Zarzuty wobec papieskiego dokumentu}

Od razu po ogłoszeniu Humanae vitae papież Paweł VI musiał się zmierzyć z falą ostrej krytyki. Ogłoszenie encykliki zbiegło się w czasie z niemalże rewolucyjnym wrzeniem, jakie ogarnęło akademickie i kulturowe centra Europy Zachodniej. Atmosfera buntu nie tylko wobec ówczesnych struktur władzy, ale także wobec tradycyjnej moralności, określanej pogardliwie jako „moralność obywatelska” (Bürgermoral), doprowadziła ostatecznie do tego, co z perspektywy czasu zostało nazwane ,rewolucją seksualną”. Na fali postulatów odrzucenia wszelkich norm moralnych dotyczących szczególnie sfery seksualnej encyklika Pawła VI była swoistym kontrapunktem (por. Merecki 2018, s. 66-68) dla propagowanej wówczas wizji seksualności i musiała stać obiektem zajadłej krytyki, gdyż jej treść była diametralnie odmienna od podnoszonych postulatów.

W opinii krytyków papieska wypowiedź stanowiła potwierdzenie konserwatyzmu Kościoła katolickiego, czyli postawy wrogiej wobec postępu zarówno technicznego (medycznego), jak i społecznego. Fakt, że najwyższy autorytet Kościoła odrzucił antykoncepcję jako działanie niemoralne, stanowił koronny argument dla tych, którzy zawsze widzieli w katolicyzmie największego wroga postępu, próbującego ukryć swój brak kompetencji pod osłoną moralnych zakazów. Zarzut braku kompetencji był wiązany z całością katolickiej doktryny moralnej dotyczącej małżeństwa. To, że najwyższe stanowiska w Kościele piastowane są przez celibatariuszy - zdaniem krytyków - dyskwalifikowało ich jako niekompetentnych w odniesieniu do kwestii małżeńsko-rodzinnych $^{2}$. Według przeciwników Humanae vitae cała katolicka etyka seksualna jest naznaczona rygoryzmem, mającym swoje źródło właśnie w fakcie, że została rzekomo stworzona przez celibatariuszy jako środek dyscyplinowania i zachowania karności wśród wierzących, a jej rygoryzm odzwierciedla też postawę wrogą wobec cielesności i seksualności, którą Kościół odziedziczył po nauczaniu niektórych autorytetów z pierwszych wieków chrześcijaństwa, pozostających pod wpływem platonizmu. Podnoszono również zarzut socjologiczny: większość ludzi, także wierzących, nie tylko nie rozumie zawartych w encyklice zasad, ale także ich nie akceptuje i nie jest gotowa zmienić swojego zdania w tej materii. Wreszcie formułowano zarzut czysto pragmatyczny. Zgodnie z nim nauka moralna Humanae vitae była niezwykle trudna do praktycznego wcielenia $\mathrm{w}$ życie, a $\mathrm{z}$ racji sporego marginesu niepewności metod wskazanych jako moralnie dopuszczalne - także nieprzydatna w realizacji zadania odpowiedzialnego rodzicielstwa.

\footnotetext{
${ }^{2}$ Odnośnie do tego zarzutu zob. Chyrowicz 2018, s. 26-35.
} 
Zarzuty powyższe odzwierciedlały rozpowszechnione stereotypy i uprzedzenia wobec Kościoła katolickiego. Wiele z nich świadczyło raczej o tym, że formułujący je krytycy albo nie czytali uważnie papieskiego dokumentu, albo też nie chcieli zrozumieć zawartej w nim argumentacji. Właściwie żaden z powyższych zarzutów nie dotyka centralnej nauki Humanae vitae, a raczej koncentruje się wokół pytania o kompetencję i władzę, a więc o to, komu wolno i kto powinien decydować o normach moralności małżeńskiej. Trzeba przyznać, że argumentacja zawarta w encyklice wielokrotnie z naciskiem odwołuje się do autorytetu Magisterium Kościoła. Od razu na początku encykliki Paweł VI bardzo dobitnie podkreśla konieczność uznania rozstrzygnięć Magisterium przez każdego wierzącego katolika, co może stworzyć wrażenie, że moralność katolicka jest w ostatecznym rozrachunku autorytarna. Nie jest to oczywiście prawdą. Zgodnie z katolicką koncepcją moralności seksualnej Magisterium nie ma władzy tworzenia norm moralnych, ale jedynie formułuje przesłanie moralne płynące $\mathrm{z}$ objawienia i Tradycji bądź też potwierdza to, co dla nieuprzedzonego człowieka wynika ze spojrzenia na ludzką naturę ${ }^{3}$. Chociaż w kontekście chrześcijańskiej etyki ostatecznym źródłem norm moralnych jest Stwórca, jednak ich moc zobowiązująca nie pochodzi z arbitralnej decyzji Boga, ale z tego, jak stworzony został przez Niego człowiek i jakie wymogi wiążą się z jego osobową cielesno-duchową naturą. Normy moralne stanowią po prostu zasady będące warunkiem osobowego spełnienia człowie$\mathrm{ka}$, w tym wypadku spełnienia związanego z relacją małżeńską.

Obok wymienionych zarzutów pojawiła się również krytyka rzeczowa, związana ze sposobem uzasadnienia zawartej w encyklice nauki moralnej. Wśród formułowanych zarzutów do najpoważniejszych należał zarzut biologizmu. Również ten zarzut nie był w gruncie rzeczy nowy, ale treść Humanae vitae stanowiła asumpt do ponownego poddania krytyce całej nauki moralnej Kościoła dotyczącej małżeństwa. Zdaniem krytyków, argumentacja encykliki odwołuje się wyłącznie do prawidłowości biologicznych podniesionych do rangi normy moralnej. Paweł VI pozostał przez to rzekomo na poziomie argumentacji nawiązującej do dawnej, niejako przednaukowej koncepcji prawa naturalnego, podczas gdy Sobór Watykański II argumentację tego typu odsunął na drugi plan, zastępując ją personalistyczną wizją osoby, małżeństwa i rodziny. Zabierając głos bezpośrednio po opublikowaniu encykliki, Bernhard Häring stwierdził w odniesieniu do Humanae vitae, że „biologiczny rytm uchodzi za absolutną normę dla całej osoby" (Häring 1968, s. 30). Zdaniem

\footnotetext{
${ }^{3}$ Nie oznacza to, że orzeczenia Magisterium w kwestii etyki seksualnej są drugorzędne. Jak wszystkie wypowiedzi zwyczajnego Magisterium Kościoła, tak też nauka Pawła VI, potwierdzona przez jego następców na Stolicy Piotrowej, obowiązuje wierzących Kościoła katolickiego w sumieniu, co zostało jeszcze bardziej wyakcentowane przez Jana Pawła II. Jednak ich siła argumentacyjna nie opiera się jedynie na argumencie ,z autorytetu”.
} 
krytyków, podana przez papieża argumentacja jest wadliwa, a nadto pochodzi z dawno zrewidowanego, starożytnego obrazu wszechświata, będąc swoistą „metafizyką natury” (Hertz 1968, s. 15-19). W tym kontekście pojawiły się krytyczne pytania: Czy obok biologicznej natury, także rozum i wola, zakorzenienie historyczne i integracja w ramach ludzkiego społeczeństwa nie należą do całościowo rozumianej natury ludzkiej? (David 1968, s. 11). Czy więc kwestii odpowiedzialnego rodzicielstwa nie należało pozostawić rozumnemu i odpowiedzialnemu rozeznaniu małżonków, nie zobowiązując ich do posłuszeństwa prawom związanym z biologiczną strukturą ich ciał?

Te krytyczne głosy, podnoszone także dzisiaj, przywołują figurę argumentacyjną, określaną jako „błąd naturalistyczny” (naturalistic failure - por. Ernst 2015, s. 171-172) ${ }^{4}$. Błąd ten polega na nieuprawnionym przejściu od stwierdzeń opisujących zjawiska naturalne do stwierdzeń zawierających imperatywy moralne. Ze stwierdzeń, że coś ,jest” lub „nie jest” takie czy inne, nie da się bezpośrednio wyprowadzić stwierdzeń, że coś „powinno być” lub „nie powinno być" właśnie takie. Biologiczne fakty jako takie nie mają jeszcze żadnej etycznej mocy zobowiązującej (Fraling 1995, s. 204-205). Zdaniem krytyków, przykładem błędu naturalistycznego była właśnie użyta w Humanae vitae argumentacja, w ramach której - jak to zrozumiano - zakaz stosowania antykoncepcji uzasadniony został nierozerwalnym i ustanowionym przez Stwórcę powiązaniem aktu seksualnego ze zdolnością prokreacyjną. Według krytyków taka konstrukcja bazuje na starożytnych arystotelesowsko-stoickich wyobrażeniach o strukturze Wszechświata i nie można jej już dzisiaj zaakceptować (Hertz 1968, s. 17). Czy jednak argumentacja użyta przez Pawła VI jest rzeczywiście właśnie w ten sposób skonstruowana?

\section{Zakaz antykoncepcji w Humanae vitae w kontekście nauczania następ- ców Pawła VI}

Trzeba przyznać, że w tekście encykliki Pawła VI są fragmenty, które z pozoru potwierdzają zarzut błędu naturalistycznego czy też biologizmu, a więc bezpośredniego wywodzenia norm moralnych z uwarunkowań biologicznych. Przykładem tego może być choćby fragment, w którym Paweł VI wyjaśnia np. różnicę moralną między respektowaniem przez małżonków naturalnego rytmu

${ }^{4}$ W tym kontekście przywołuje się zazwyczaj szkockiego filozofa Dawida Hume'a (1711-1776), który badając sądy etyczne, wskazywał na powszechność tej błędnej drogi dowodzenia. Później ten sposób rozumowania został przez George’a Edwarda Moore’a (1873-1958) określony właśnie jako błąd naturalistyczny. Zarzut błędu naturalistycznego, który często używany jest jako wykluczający dalszą dyskusję, sam w sobie zasługuje jednak na krytykę. Szeroko i krytycznie omawia tę kwestię Fritz (2009). 
biologicznego a stosowaniem antykoncepcji. Jak pisze papież, „w pierwszym wypadku małżonkowie w sposób prawidłowy korzystają z pewnej właściwości danej im przez naturę" (HV, nr 16). To stwierdzenie może być rozumiane w ten sposób, że biologiczne uwarunkowania bezpośrednio wyznaczają sposób postępowania moralnego. Jednak w Humanae vitae znajdują się także inne stwierdzenia, które wskazują na pogłębiony, personalistyczny kontekst sformułowanej przez Pawła VI normy moralnej. Papież wskazuje na przykład, że wszelkie problemy moralne związane z życiem ludzkim nie powinny być rozpatrywane jedynie w kontekście aspektów cząstkowych, np. biologicznych, psychologicznych, demograficznych czy socjologicznych, ale w poszukiwaniu ich rozwiązania powinno się uwzględnić „całego człowieka i całe jego powołanie, obejmujące nie tylko porządek naturalny i doczesny, ale również nadprzyrodzony i wieczny" (HV, nr 7). Mimo tych deklaracji można w Humanae vitae rzeczywiście zdiagnozować pewien niedostatek argumentacji personalistycznej, przedstawionej szerzej i pogłębionej dopiero w nauczaniu następców Pawła VI, szczególnie Jana Pawła II. Już w Memoriale krakowskim, który został krótko przed ogłoszeniem encykliki przesłany Pawłowi VI przez powołaną przez kard. Karola Wojtyłę komisję, a także w opublikowanym już po ogłoszeniu encykliki przez tę samą grupę Wprowadzeniu (Bajda i in. 2012, s. 11), personalistyczny wymiar zjednoczenia małżeńskiego został wyraźnie podkreślony i omówiony. Wpływ refleksji krakowskich etyków na ostateczną decyzję Pawła VI nie ulega wątpliwości, ale mimo to przedstawiona przez nich argumentacja nie została - jak się wydaje - wystarczająco wyraźnie uwzględniona $\mathrm{w}$ tekście encykliki. Warto więc spojrzeć ponownie na Humanae vitae właśnie w kontekście tejże pogłębionej argumentacji etycznej. Uwydatnia ona trzy kluczowe aspekty.

Pierwszym aspektem jest aspekt personalistyczny, a więc personalistyczna wizja osoby ludzkiej. Różni się ona zarówno od koncepcji monistycznych, w ramach których ludzka natura (wraz z ludzką psychiką) jest postrzegana jako zespół mniej czy bardziej skomplikowanych procesów biologiczno-chemicznych, jak i od koncepcji dualistycznych, które wprawdzie uznają dwoistość osoby ludzkiej, a więc jej wymiar materialny oraz duchowy w ich odrębności, ale nie uznają dogłębnego zjednoczenia tych dwóch wymiarów w osobie. W odróżnieniu od nich koncepcja personalistyczna dostrzega znaczenie zarówno ludzkiego ducha, jak i ludzkiego ciała w ich dogłębnej jedności. Personalizm docenia osobowy, a więc świadomy i wolny charakter ludzkich działań, co nie oznacza, że człowiek jest postrzegany jako czysty duch szybujący niejako ponad cielesnym wymiarem swojej osobowej natury. Dogłębne powiązanie aspektu cielesnego i duchowego w osobie (unitotality Sgreccia 2012, s. 122) sprawia, że żadne świadome i wolne działania, a więc także aktywność seksualna, nie mogą być postrzegane jedynie w kontekście 
biologicznych procesów, ale są aktami przeżywanymi przez całą osobę ${ }^{5}$. W perspektywie personalistycznej niemożliwe jest takie używanie własnego ciała przez osobę, które nie dotykałoby jej samej (Sgreccia 2012, s. 121). $\mathrm{W}$ biologię procesów cielesnych wpisane jest głębsze znaczenie ludzkiego ciała, które Karol Wojtyła określił jako jego charakter oblubieńczy: zostało ono stworzone, by móc wyrażać miłość ${ }^{6}$. W przypadku aktu seksualnego nie mamy zatem do czynienia jedynie z biologicznymi prawidłowościami, z czystą fizjologią, którą umysł ludzki mógłby się dowolnie posłużyć do swoich celów, a więc wtórnie nadać jej jakieś ostatecznie dowolne znaczenie. Akt seksualny ma, obok biologicznego i społecznego, także symboliczne i głęboko duchowe znaczenie, gdyż jest związany z miłością oblubieńczą. Ciało nie może być w tym kontekście traktowane jedynie jako żywa materia, która reaguje w określony sposób, ale niczego nie oznacza, będąc co najwyżej środkiem do osiągnięcia przez osobę przyjemności i satysfakcji. Do personalistycznej wizji ludzkiej seksualności należy także to, że aktywność seksualna jest związana ze zdolnością prokreacyjną. Zdolność przekazywania życia jest darem, który należy do całości osoby ludzkiej. Sednem argumentacji zawartej w encyklice Humanae vitae nie jest więc nadawanie biologicznemu cyklowi kobiety czy też fizjologii rodzenia rangi normy moralnej, ale są nim wymogi chroniące podstawowe dobra osobowe ujawniające się w pogłębionym spojrzeniu na naturę osoby ludzkiej ${ }^{7}$.

Ta personalistyczna wizja osoby ludzkiej uzyskuje głębię wtedy, gdy w jej świetle widzi się drugi aspekt argumentacji Humanae vitae, jakim jest aspekt relacyjny zjednoczenia małżeńskiego. Jeżeli ma ono wyrażać dogłębnie miłość małżeńską, która - jak podkreślał w swojej encyklice Paweł VI - jest na wskroś ludzka, a więc cielesna i duchowa, pełna, a więc wyrażająca całkowite wzajemne oddanie, wierna, wyłączna oraz płodna (HV nr 9), to nie może być aktem okaleczonym, połowicznym. Każdy akt seksualny jest aktem specyficznej komunikacji, wyrażającym i aktualizującym całkowite oddanie się drugiej osobie. Ze względu na całkowitość tego oddania uzyskuje on swoje pełne znaczenie jedynie w kontekście małżeństwa, gdzie jest aktem, w którym ucieleśnia się i wyraża treść przysięgi małżeńskiej. Jej sensem jest całkowite oddanie się współmałżonkowi i przyjęcie jego/jej całkowitego daru z siebie.

${ }^{5}$ Por. Bajda i in. 2012, s. 31, przyp. 5: „Wydaje się, że zasadniczym błędem jest traktowanie przez niektórych teologów ciała ludzkiego jako należącego do natury - w rozumieniu przyrody którą człowiek może kierować dowolnie dla swojego pożytku, jako czymś, co jest od osoby niższe i od niej zależne. Ciało i dusza tworzą jedność osoby. Odnoszenie się do swojego ciała jest odnoszeniem się do siebie, kierowanie sobą".

${ }^{6}$ K. Wojtyła, Miłość i odpowiedzialność, s. 153, przyp. 67, w: http://krapiecfoundation.com/ strony 2/konkurs2017zal/Karol\%20Wojtyla\%20-\%20Milosc\%20i\%20odpowiedzialnosc.pdf [dostęp: 8.08.2018].

${ }^{7}$ Por. refleksję dotyczącą błędu naturalistycznego w: Chyrowicz 2015, s. 126-139. 
Jak podkreśla Elio Sgreccia, zjednoczenie małżeńskie wyraża komplementarność będącą jednocześnie znakiem braku domagającego się dopełnienia oraz znakiem daru ofiarującego dopełnienie (Sgreccia 2012, s. 392). Ważna jest tu także zdolność prokreacyjna, która, jak wyżej wspomniano, należy do całości osoby. Jeżeli zostanie ona świadomie okaleczona poprzez działanie antykoncepcyjne, oznacza to, że w tym wymiarze osoba współmałżonka nie jest przez drugą stronę akceptowana: jej przyjęcie dokonuje się pod warunkiem, że zostanie chemicznie lub mechanicznie spreparowana, obezpłodniona. Taki akt seksualny nie odzwierciedla przysięgi małżeńskiej, nie jest więc potwierdzeniem małżeństwa i nie jest znakiem prawdziwej miłości małżeńskiej, stąd jest moralnie wadliwy (por. FC nr 11; Laun 2000, s. 100-101; Noonan 1986, s. 537). „Pozbawienie siebie czy partnera wielkiego daru, którym jest płodność po to, by osiągnąć rozkosz lub przeżyć uczuciowo miłość jest równoznaczne z użyciem partnera dla swojego celu, a zatem sprzeciwia się jego osobowej godności” (Bajda i in. 2012, s. 24). Jest to działanie, jak podkreślał Paweł VI w swojej encyklice, „wbrew naturze tak mężczyzny jak i kobiety, a także wbrew głębokiemu ich zespoleniu" (HV nr 13). Miłość małżonków, jeżeli jest prawdziwa i pełna, nie może pozostawać zamknięta na dar życia. Punktem odniesienia jest więc tu nie tylko natura osób, mężczyzny i kobiety, ale także natura ludzkiej miłości, a więc prawda tej specyficznej formy komunikacji międzyosobowej, jaką jest akt seksualny. Podkreślić przy tym należy raz jeszcze, że prawda ta, odnosząca się do powiązania wymiaru jednoczącego i prokreacyjnego w zjednoczeniu małżeńskim, dotyczy nie tyle związku między rzeczami (w sensie biologicznych faktów), ile związku między znaczeniami (por. Noonan 1986, s. 543). Tak należy więc rozumieć kluczowe zdanie Humanae vitae, że podstawa przedstawionej tam nauki tkwi w nierozerwalnym związku „między dwojakim znaczeniem tkwiącym w stosunku małżeńskim: między oznaczaniem jedności i oznaczaniem rodzicielstwa" (HV nr 12). Trudno zatem mówić tu o błędzie naturalistycznym. Kluczem do zrozumienia przesłania encykliki Humanae vitae pozostaje zatem - jak stwierdził Benedykt XVI - osobowa miłość między małżonkami, która szanuje godność osoby ${ }^{8}$.

Dopełnieniem argumentacji encykliki jest trzeci aspekt - aspekt teologiczny. Zrozumienie związku znaczeń aktu małżeńskiego, a więc znaczenia jedności i rodzicielstwa - chociaż możliwe także bez odniesienia do Boga ${ }^{9}$ - zostaje w świetle wiary jeszcze bardziej pogłębione. W kontekście wiary

\footnotetext{
${ }^{8}$ Benedykt XVI, Encyklika, która stała się znakiem sprzeciwu. Przemówienie do uczestników kongresu z okazji 40-lecia encykliki Pawta VI „Humanae vitae”, https://opoka.org.pl/biblioteka/W/ WP/benedykt_xvi/przemowienia/rocz_hv_10052008.html [dostęp: 5.08.2018].

${ }^{9}$ Pracownicy poradni naturalnego planowania rodziny, szczególnie pracujących w społeczeństwach mocno zsekularyzowanych, podkreślają, że większość osób pragnących nauczyć się metod
} 
związek ten jest postrzegany jako związek znaczeniowy ustanowiony przez Boga (FC, nr 32). Stwierdzenie Pawła VI, że „małżeństwo [...] nie jest wyrokiem jakiegoś przypadku lub wynikiem ewolucji ślepych sił przyrody" (HV, nr 8), wskazuje na odmienność perspektywy wiary od perspektywy ewolucyjnej. W ramach tej ostatniej ludzka natura jest wynikiem uwarunkowań ślepych sił przyrody, zatem doszukiwanie się w niej jakichkolwiek znaczeń moralnych jest traktowane jako nieuprawniona projekcja. Ludzka aktywność seksualna pozostaje tu kwestią fizjologii analogicznej do seksualności zwierzęcej. Człowiek przeżywa ją wprawdzie także na płaszczyźnie psychiczno-emocjonalnej, jednak nie zawiera się w tym żadna normatywność, której powinien być posłuszny. Tymczasem w perspektywie katolickiej natura ludzka jest - jak to sformułował Benedykt XVI - przejrzysta na przesłanie moralne i nosi w sobie ,język Logosu"10. Nie ogranicza się on jedynie do wymiaru matematycznego, dostępnego dla metody empirycznej, ale obejmuje także wymiar estetyczny, a przede wszystkim moralny. Odczytanie Logosu natury ludzkiej ujawnia, że nie jest ona dana człowiekowi jedynie jako czysta biologia. Teologiczny wymiar nauki Humanae vitae dotyczy także wymiaru rodzicielskiego aktu seksualnego. Tam, gdzie osoby dają początek nowej osobie, Bóg jest obecny w sposób wyjątkowy, gdyż jedynie we współpracy ze Stwórcą może się dokonać stworzenie nowej osoby ludzkiej (por. Twomey 2008, s. 189).

Biorąc pod uwagę wszystkie trzy omówione wyżej aspekty, Jan Paweł II stwierdza:

Kiedy małżonkowie, uciekając się do środków antykoncepcyjnych, oddzielają od siebie dwa znaczenia, które Bóg Stwórca wpisał w naturę mężczyzny i kobiety i w dynamizm ich zjednoczenia płciowego, zajmują postawę „sędziów” zamysłu Bożego i „manipulują” oraz poniżają płciowość ludzką, a wraz z nią osobę własną i współmałżonka, fałszując wartość „całkowitego” daru z siebie. W ten sposób naturalnej „mowie”, która wyraża obopólny, całkowity dar małżonków, antykoncepcja narzuca „mowę” obiektywnie sprzeczną, czyli taką, która nie wyraża całkowitego oddania się drugiemu; stąd pochodzi nie tylko czynne odrzucenie otwarcia się na życie, ale również sfałszowanie wewnętrznej prawdy miłości małżeńskiej, powołanej do całkowitego osobowego daru (FC, nr 32).

Jeżeli jednak małżonkowie respektują pełną prawdę ich małżeńskiego zjednoczenia, ,[...] płciowość zostaje uszanowana i rozwinięta w jej wymia-

naturalnego planowania rodziny kieruje się motywacją, która można by określić jako ekologiczną, a nie motywacją religijną.

${ }^{10}$ Por. Benedikt XVI, Ansprache an die Teilnehmer an dem von der Päpstlichen Lateranuniversität veranstaltete Internationalen Kongress über das natürliche Sittengesetz (12 II 2007), http://www.vatican.va/holy_father/benedict_xvi/speeches/2007/february/documents/hf_ben-xvi_ spe_20070212_pul_ge.html [dostęp: 8.08.2018]. Także Ratzinger (2007, s. 57). 
rze prawdziwie i w pełni ludzkim, nie jest natomiast «używana» jako «przedmiot», który burząc jedność osobową duszy i ciała, uderza w samo dzieło stwórcze Boga w najgłębszym powiązaniu natury i osoby" (FC, nr 32). Odkrywając zawarty w swojej aktywności seksualnej wymiar moralny, małżonkowie mają szansę osiągnąć rzeczywistą głębię swojego wzajemnego związku. Gdy wymiar ten nie jest respektowany, małżeństwu grozi status „wspólnoty hotelowej”, wspólnoty wzajemnych usług, również seksualnych, w której brakuje głębi wzajemnego oddania.

\section{Humanae vitae w kontekście nauczania papieża Franciszka}

Kontrowersje wokół encykliki Pawła VI trwają do dziś. Zawarte w Amoris laetitia, a pochodzące z dokumentu końcowego Synodu o rodzinie wezwanie, by dokonać relektury encykliki Humanae vitae i na nowo odczytać zawarte w niej przesłanie (AL, nr 82), przyczyniło się wprawdzie do nowego zainteresowania dokumentem Pawła VI, chociaż dominuje dawne krytyczne podejście. Pojawiają się próby ponownego odczytania centralnego argumentu Humanae vitae dotyczącego wewnętrznego związku dwóch znaczeń zawartych w akcie małżeńskim: znaczenia jedności i rodzicielstwa. Niektórzy autorzy próbują konstruować pewną opozycję między Pawłem VI a Janem Pawłem II, sugerując, że dopiero ten ostatni nadał zakazowi antykoncepcji znaczenie nieprzekraczalnej normy moralnej (por. Lintner 2018, s. 75-87). Zawarte w Humanae vitae, a skierowane do spowiedników wezwanie do okazywania pastoralnego miłosierdzia i cierpliwości wobec małżonków, którzy mieliby trudności w zachowaniem normy, nie znalazło rzekomo odzwierciedlenia w nauczaniu Jana Pawła II, które ma cechować „,moralny rygoryzm i nieprzejednana bezkompromisowość" (Lintner 2018, s. 87) ${ }^{11}$. Twierdzi się też, że Benedykt XVI miał rzekomo dokonać „ostrożnej korekty” nauczania Pawła VI poprzez swoją ,nobliwą wstrzemięźliwość” w wypowiedziach na ten temat (Schockenhoff 2016, s. 358). Powierzchowny ogląd tekstu adhortacji Amoris laetitia oraz innych wypowiedzi papieża Franciszka wprawdzie nie pozostawia wątpliwości co do jego pełnej aprobaty nauczania Pawła VI zawartego w Humanae vitae oraz w wypowiedziach jego następców. Nie brak jednak komentatorów, którzy interpretują nauczanie Franciszka odmiennie, twierdząc, że zainicjował on zmianę paradygmatu w odniesieniu do całej katolickiej etyli seksualnej, a więc ostatecznie także zmianę kluczowych norm moralnych. Miałoby to dowodzić,

${ }^{11}$ Ten skierowany pod adresem papieża-Polaka zarzut jest akurat kompletnie nieuzasadniony, zważywszy zawarte w wielu miejscach jego nauczania, szczególnie w adhortacji Familiaris consortio stwierdzenia dotyczące stopniowego dochodzenia do pełnej akceptacji nauczania Kościoła w tej materii, zawarte w określeniu: ,prawo stopniowości” (FC nr 34). 
że kwestia moralnego zakazu antykoncepcji zostaje poddana dogłębnej rewizji. Stosowany jest przy tym szczególny klucz hermeneutyczny, według którego ważne jest nie tylko i nie tyle to, co papież napisał czy powiedział, ale bardziej to, co - zdaniem interpretatorów - świadomie przemilczał. Trzeba wziąć pod uwagę, że „nawet to, co nie jest powiedziane, coś wyraża” (Kasper 2018, s. 62; podobnie Schockenhoff 2016, s. 360). W ten sposób kard. Walter Kasper komentuje fakt, że papież Franciszek wyraził wprawdzie w Amoris laetitia zachętę do respektowania naturalnej metody regulacji poczęć (AL nr 222), jednak nie wypowiedział się na temat oceny moralnej innych metod, także sztucznych. Na podstawie tego przemilczenia, powiązanego z faktem, że w Amoris laetitia w odniesieniu do naturalnych metod mówi się o ,zachęcie”, a nie o ,normie" (AL nr 222; por. także Lintner 2018, s. 101-106), wyprowadza się wniosek, iż ,planowanie rodziny w sensie odpowiedzialnego rodzicielstwa, jak uczył Sobór Watykański II, ma zostać pozostawione odpowiedzialnej decyzji sumienia małżonków" (Kasper 2018, s. 62). Podkreślany przez Pawła VI nierozerwalny związek między jednoczącym i prokreacyjnym znaczeniem aktywności seksualnej miałby pozostać w mocy, pod warunkiem wszakże, że zostanie on odniesiony do całości życia seksualnego w małżeństwie, a nie do każdego poszczególnego aktu małżeńskiego. Stosowana przez małżonków konkretna metoda regulacji poczęć, zarówno naturalna, jak i sztuczna, miałaby być kwestią ich dokonanego w sumieniu wyboru, zależnego od ich konkretnej sytuacji. Zdaniem E. Schockenhoffa, taka modyfikacja nauczania byłaby jedynie kolejnym etapem w rozwoju doktryny kościelnej dotyczącej etyki seksualnej, a nie zerwaniem z dotychczasową nauką Kościoła w tej dziedzinie (Schockenhoff 2016, s. 356-357).

Na potrzebę albo wręcz konieczność tego rodzaju „relektury” nauczania Kościoła w jego opinii wskazuje przede wszystkim fakt, że wielu, jeżeli nie większość, wiernych ma trudności w postępowaniu zgodnym z normą zawartą w Humanae vitae. Ten brak ,rezonansu w świadomości wiary Kościoła” (Schockenhoff 2016, s. 351) - jak to określa Eberhard Schockenhoff - jest znakiem istotnego defektu, jakim jest rzekomo naznaczona encyklika Humanae vitae, a który dyskwalifikuje zawarty w niej zakaz antykoncepcji.

Trudno oprzeć się wrażeniu, że przedstawione powyżej argumenty, akcentujące bardziej rzekome przemilczenia, a nie zawarte w dokumentach Magisterium treści, są wysoce problematyczne. Takie podejście jest zupełnie nieprzekonujące i wyraża raczej coś w rodzaju myślenia życzeniowego niż prawdziwe intencje zawarte $\mathrm{w}$ dokumentach Magisterium. Warto więc wobec niego sformułować szereg krytycznych pytań. Propozycja, by zasada nierozerwalnego związku między jednoczącym i prokreacyjnym znaczeniem aktów seksualnych odnosiła się do całości małżeństwa, a nie do poszczególnych aktów, nie jest nowa. Była ona podnoszona jeszcze przed ogłoszeniem Humanae 
vitae, a w samej encyklice Paweł VI ją tematyzuje i odrzuca (HV, nr 14). Pojedynczy stosunek płciowy może oczywiście uczestniczyć w płodności całego małżeństwa, ale jedynie wtedy, gdy istnieje ku temu podstawa (por. Bajda $\mathrm{i}$ in. 2012, s. 38). Jest nią rodzicielski charakter miłości małżeńskiej, którą każdy akt seksualny powinien wyrażać i zachowywać. Trudno przekonująco zakładać, że akt małżeński świadomie uczyniony niepłodnym miałby wyrażać płodność miłości małżeńskiej. Zresztą, tak rozumiany „ideał” płodnej miłości małżeńskiej rozumianej jako suma wszystkich aktów małżeńskich straciłby jakiekolwiek znaczenie, gdyż w praktyce wpływałby na wybory małżonków jedynie w bardzo ograniczonym czasie ich życia (czyli wtedy, gdy chcieliby począć dziecko), podczas gdy ogromna większość zbliżeń małżeńskich byłaby poprzez antykoncepcję pozbawiona pełnego znaczenia, jakie wpisane zostało w ludzką seksualność.

Nie przekonuje także uzasadnianie postulatu zmiany katolickiej nauki o antykoncepcji poprzez akcentowanie odpowiedzialności małżonków, których decyzje dotyczące stosowanych metod i środków regulacji poczęć, zarówno naturalnych, jak i sztucznych, należy tak samo respektować. W tle takich stwierdzeń leży zanegowanie różnicy między postawą tych małżonków, którzy stosując naturalne metody, odkładają poczęcie dziecka, a tych, którzy dla osiągnięcia tego samego celu uciekają się do sztucznej antykoncepcji. Różnica taka - i to zasadnicza - jednak istnieje. W przypadku niepogłębionego i lekkomyślnego podejścia do życia seksualnego może to być różnica „między rozumnym działaniem, świadomym skutków, które ono za sobą pociąga, a przezornym zapobieganiem skutkom nierozumnego działania" (por. Bajda $\mathrm{i}$ in. 2012, s. 42). Jednak najistotniejsza jest różnica pomiędzy dostrzeganiem głębokiego znaczenia ludzkiej płciowości wpisanego w naturę osoby, jak też natury prawdziwej ludzkiej miłości, a widzeniem w akcie seksualnym jedynie jego funkcji.

Bardzo poważnie trzeba oczywiście potraktować zarzut odrzucenia nauczania Humanae vitae przez znaczne rzesze wiernych. Rozdźwięk w relacji między Urzędem Nauczycielskim Kościoła a nie tylko znacznymi kręgami teologów katolickich, ale także wieloma wiernymi, szczególnie małżonkami, musi niepokoić i boleśnie ranić Kościół. W wyniku ankiety przeprowadzonej przed synodem o rodzinie w 2014 i 2015 roku ujawniono nie tylko brak akceptacji wielu wiernych dla nauki Humanae vitae, ale także - i jest to znamienne! - zrozumienie i akceptację tej nauki w gronie osób należących do ruchów i grup wiernych, w których dokonuje się intensywna formacja ${ }^{12}$. Jednak również wobec tego zarzutu należy krytycznie zapytać, czy taki stan

${ }^{12}$ Włoski tekst Instrumentum laboris z 2014 r. zob. http://www.vatican.va/roman_curia/synod/ documents/rc_synod_doc_20140626_instrumentum-laboris-familia_it.html [dostęp: 5.08.2018]. 
rzeczy można po prostu interpretować jako efekt zignorowania zmysłu wiary osób wierzących (sensus fidei fidelium) przez hierarchię kościelną? Kościół nigdy nie ignorował opinii społecznej, traktując ją jako znak czasu, który należy poważnie brać pod uwagę, bądź też jako locus theologicus, a więc „miejsce”, gdzie ujawnia się jakiś istotny element prawdy lub poważne wyzwanie dotyczące wiary. Nigdy jednak opinia arytmetycznej większości nie była traktowana jako źródło, na którym można i należy opierać wiarę Kościoła. Historia Kościoła zna sytuacje, gdy znaczna część wierzących i niemało pasterzy odchodziło od wiary Kościoła. Stosowanie w kontekście pojęcia sensus fidelium wyłącznie kryteriów liczbowych jest o tyle nieodpowiednie, że pojedynczy ochrzczeni znajdują się w bardzo różnym miejscu swojej osobistej drogi wiary: jedni rzeczywiście usiłują żyć zgodnie ze swoją wiarą, inni, poza faktem chrztu, nie mają ze spojrzeniem wiary wiele wspólnego. Ostrożność w wyprowadzaniu zbyt pochopnych wniosków jest tu tym bardziej wskazana, że postulat zmiany etyki seksualnej Kościoła jest w oczywisty sposób podobny do roszczeń formułowanych przez środowiska jawnie wrogie nie tylko wobec chrześcijańskiej nauki moralnej, ale generalnie wobec chrześcijańskiej wiary. Należy zatem krytycznie zapytać, czy wspomniany wyżej brak akceptacji płynie z lepszego zrozumienia woli Bożej przez większość domagającą się zmiany zasad moralności, czy też z kapitulacji tej większości przed sugestywnym naciskiem opinii społecznej i medialnej obcej chrześcijańskiej wierze? ${ }^{13}$

Przesłanie encykliki Humanae vitae można by określić jako odpowiedź na pytanie: Pod jakimi warunkami ludzka aktywność seksualna będzie w pełni odpowiadała cielesno-duchowej naturze osób oraz pełnej i prawdziwej miłości małżeńskiej? Innymi słowy: Jaka jest „gramatyka” owej mowy ciała, której formą jest każdy akt seksualny? Kiedy ta mowa ciała będzie mową prawdziwą i niezafałszowaną? Paweł VI w encyklice Humanae vitae, a po nim jego następcy, stwierdzają, że będzie nią wtedy, gdy zostaną uszanowane znaczenia wpisane w to specyficzne spotkanie dwojga osób; gdy każdy akt seksualny po-

13 Por. W. Brandmüller, Kardynat Walter Brandmueller o różnicy między opinią publiczną a zmysłem wiary, w: http://www.pch24.pl/kardynal-walter-brandmueller-o-roznicy-miedzy-opiniapubliczna-a-zmyslem-wiary,59475,i.html\#ixzz5NaF3JRb2 [dostęp: 8.08.2018]: „Zatem kiedy katolicy en masse uważają, że prawowitą rzeczą jest wstąpienie w ponowny związek małżeński po rozwodzie, stosowanie antykoncepcji czy coś podobnego, to nie jest to masowe świadectwo dawane wierze, ale masowe od niej odchodzenie. Sensus fidei to nie byt, który może być określany demokratycznie, poprzez badanie opinii publicznej. Jedyną kwestią jest to, w jaki sposób masowe świadectwo różni się od masowego wyobcowania. Zatem już św. Jan Paweł II podkreślił potrzebę starannego odróżnienia pomiędzy „opinią publiczną” a sensus fidei fidelium. 
zostanie znakiem i wyrazem całkowitego oddania się sobie dwojga ludzi, a zatem ich prawdziwej i wiernej miłości oblubieńczej; gdy będzie odzwierciedlał ich całkowity dar z siebie, wzajemnie ofiarowany i przyjęty w małżeństwie oraz gdy akt ten uszanuje, a nie sztucznie wyłączy ich zdolność prokreacyjną. To przesłanie Humanae vitae, mimo poważnych trudności od samego momentu ogłoszenia encykliki do dzisiaj, nie uległo dezaktualizacji także po upływie pięćdziesięciu lat.

\section{THE MESSAGE OF HUMANAE VITAE FROM THE PERSPECTIVE OF THE FIFTY YEARS SINCE THE PUBLISHING OF THE ENCYCLICAL}

\section{Summary}

The author of this article explores the understanding of the message of the encyclical Humanae vitae based on three crucial points. The first one concerns the concept of human person. Unlike the evolutionary approach wherein the human being is thought under the aspect of its biological facticity, human person is viewed here as a "unitotality", an indissolubly whole of the body and the soul whereby the human body has not only a function but also reveals a deeper meaning. The second point is the nature of the conjugal act. It exhibits the reciprocal gift of a man and a woman in their totality as persons. Due to this totality the two meanings contained in the conjugal act, namely the meaning of loving personal unity and the meaning of procreativeness should not be consciously separated. The matter is hereby not a bond between two things or biological facts but a bond between meanings. The objection of the naturalistic fallacy is also here unjustified. Finally the third point is the theological dimension which highlights that the double meaning of the conjugal act comes from God the Creator and as innate into the human nature and the nature of human love and as such should be respected. The contemporary controversy concentrates the question either the sexuality-conjugality-procreation nexus concerns every single conjugal act or if it might concern the marital life as a whole whereas the married couple can make some single sexual acts consciously unfruitful.

Keywords: Humanae vitae; contraception; naturalistic fallacy; conjugal act; marriage; Amoris laetitia; human body; natural family planning

Słowa kluczowe: Humanae vitae; antykoncepcja; błąd naturalistyczny; akt małżeński; małżeństwo; Amoris laetitia; ciało człowieka; naturalne planowanie rodziny 


\section{BIBLIOGRAFIA}

Bajda J. i in. (2012), Memoriat krakowski: uzasadnienie katolickiej nauki tyczacej podstaw moralnych życia małżeńskiego, Kraków 1968. Wprowadzenie do encykliki Humanae vitae, Kraków 1969, Poznań.

Chyrowicz B. (2015), Bioetyka. Anatomia sporu, Kraków.

Chyrowicz B. (2018), Twarda mowa papieża, „W Drodze” 7, s. 26-35.

David J. (1968), Zerreißprobe in der Kirche, w: Erstes Echo auf Humanae vitae. Dokumentation wichtiger Stellungnahmen zur umstrittenen Enzyklika über die Geburtenkontrolle, red. F. Oertel, Essen, s. 10-12.

Ernst S. (2015), Argumentationsmodelle in der theologischen Sexual- und Beziehungsethik, w: Zukunftshorizonte katholischer Sexualethik, Questiones Disputatae 241, Hrsg. K. Hilpert, Freiburg-Basel-Wien, s. 162-184.

Fraling B. (1995), Sexualethik. Ein Versuch aus christlicher Sicht, Paderborn-München-WienZürich.

Fritz A. (2009), Der naturalistische Fehlschluß. Das Ende eines Knock-Out-Arguments, FreiburgWien.

Häring B. (1968), Krise um „Humanae vitae“, w: Erstes Echo auf Humanae vitae. Dokumentation wichtiger Stellungnahmen zur umstrittenen Enzyklika über die Geburtenkontrolle, red. F. Oertel, Essen, s. 29-31.

Hertz A. (1968), Naturrechtsmetaphysik oder Heilsbotschaft?, w: Erstes Echo auf Humanae vitae. Dokumentation wichtiger Stellungnahmen zur umstrittenen Enzyklika über die Geburtenkontrolle, red. F. Oertel, Essen, s. 15-23.

Kasper W. (2018), Die Botschaft von Amoris laetitia. Ein Freundschaftlicher Disput, Freiburg-Basel-Wien.

Laun A. (2000), Liebe und Partnerschaft aus katholischer Sicht, Eichstädt.

Lintner M.M. (2018), Von Humanae vitae bis Amoris laetitia. Die Geschichte einer umstrittenen Lehre, Innsbruck-Wien.

Merecki J. (2018), Pokochać ludzką miłość, „W Drodze” 7, s. 64-73.

Noonan J.T. (1986), Contraception. A History of its Treatment by the Catholic Theologians and Canonists, Cambridge MA-London.

Odin K.A. (1968), Zur Rechenschaft herausgefordert, w: Erstes Echo auf Humanae vitae. Dokumentation wichtiger Stellungnahmen zur umstrittenen Enzyklika über die Geburtenkontrolle, red. F. Oertel, Essen, s. 49-51.

Ratzinger J. (2007), Wprowadzenie w chrześcijaństwo, tłum Z. Włodkowa, Kraków.

Sgreccia E. (2012), Personalist bioethics. Foundations and Applications, Philadelphia.

Twomey V. (2008), Der Papst, die Pille und die Krise der Moral, Augsburg.

Schockenhoff E. (2016), Der Glaubenssinn des Volkes Gottes als ethisches Erkenntniskriterium? Zur Nicht-Rezeption der kirchlichen Sexualmoral durch die Gläubigen, „Theologie und Philosophie" 91, s. 321-362.

\section{Publikacje internetowe}

Benedikt XVI., Ansprache an die Teilnehmer an dem von der Päpstlichen Lateranuniversität veranstaltete Internationalen Kongress über das natürliche Sittengesetz (12 II 2007), http://www.vati can.va/holy_father/benedict_xvi/speeches/2007/february/documents/hf_ben-xvi_spe_20070212_ pul_ge.html [dostęp: 8.08.2018].

Benedykt XVI, Encyklika, która stała się znakiem sprzeciwu. Przemówienie do uczestników kongresu z okazji 40-lecia encykliki Pawła VI „Humanae vitae”, https://opoka.org.pl/biblioteka/W/ WP/benedykt_xvi/przemowienia/rocz_hv_10052008.html [dostęp: 5.08.2018]. 
Brandmüller W., Kardynał Walter Brandmueller o różnicy między opinia publiczną a zmystem wiary, http://www.pch24.pl/kardynal-walter-brandmueller-o-roznicy-miedzy-opinia-publiczna-azmyslem-wiary,59475,i.html\#ixzz5NaF3JRb2 [dostęp: 8.08.2018].

Franciszek, Posynodalna adhortacja apostolska Amoris laetitia o mitości w rodzinie, https://opo ka.org.pl/biblioteka/W/WP/franciszek_i/adhortacje/amoris_laetitia_19032016.html [dostęp: 8.08.2018].

Jan Paweł II, Adhortacja apostolska Familiaris consortio o zadaniach rodziny chrześcijańskiej $w$ świecie wspótczesnym, https://opoka.org.pl/biblioteka/W/WP/jan_pawel_ii/adhortacje/fami liaris.html [dostęp: 8.08.2018].

Paweł VI, Encyklika Humanae vitae o zasadach moralnych $w$ dziedzinie przekazywania życia ludzkiego, https://opoka.org.pl/biblioteka/W/WP/pawel_vi/encykliki/humane.html [dostęp: 8.08.2018].

Sinodo dei Vescovi, III Assemblea Generale Straordinaria le Sfide Pastorali Sulla Famiglia nel Contest dell' Evangelizzazione. Instrumentum laboris, http://www.vatican.va/roman_curia/ synod/documents/rc_synod_doc_20140626_instrumentum-laboris-familia_it.html [dostęp: 5.08.2018].

MARIAN MACHINEK - kapłan Zgromadzenia Misjonarzy Świętej Rodziny (MSF), profesor teologii na Uniwersytecie Warmińsko-Mazurskim w Olsztynie, w latach 1999-2018 kierownik Katedry Teologii Moralnej i Etyki, redaktor naczelny czasopisma „Studia Nauk Teologicznych PAN”, członek Komitetu Nauk Teologicznych PAN, w latach 2013-2019 przewodniczący Stowarzyszenia Teologów Moralistów. Obszary badawcze: wybrane zagadnienia bioetyczne, moc zobowiązująca etosu biblijnego, zagadnienie sumienia, elementy antropologii teologiczno-moralnej, zagadnienia etyczne małżeństwa i rodziny. 